\title{
A Rapid Protocol for Evaluating Prunus Germplasm for Tomato Ringspot Virus Resistance
}

\author{
J.M. Halbrendt \\ Fruit Research Laboratory, Pennsylvania State University, Biglerville, \\ PA 17307
}

\author{
E.V. Podleckis and A. Hadidi \\ United States Department of Agriculture, Agricultural Research Service, \\ National Germplasm Resources Laboratory, Beltsville, MD 20705
}

\section{R. Scorza}

United States Department of Agriculture, Agricultural Research Service, Appalachian Fruit Research Station, Kearneysville, WV 25430

\author{
R. Welliver \\ Pennsylvania Department of Agriculture, Harrisburg, PA 17109
}

Additional index words. dot blot, hybridization, peach, rootstock, Xiphinema

\begin{abstract}
Rooted cuttings of 'Halford' and 'Redhaven' peaches [Prunus persica (L.) Batsch] and 'Stanley' (Prunus domestica L.) and 'Marianna 2624' (P. cerasifera $x$ P. munsoniana) plums were planted in soil containing $\approx 38$ tomato ringspot virus- (TomRSV) infested nematodes (Xiphinema americanum sensu lato Cobb) per 100 cc. Test- and control-plant sap extracts were made from root and leaf tissues after 10, 22, and 34 weeks. Aliquots of these samples were assayed by mechanical inoculation to Chenopodium quinoa Willd. Total nucleic-acid extracts prepared from the remainder of each sample were analyzed by dot blot hybridization using a cRNA probe for TomRSV. The bioassay identified one 'Stanley' and two 'Redhaven' infected plants. Hybridization results indicated that two of two 'Stanley', three of three 'Halford', five of five 'Redhaven', and zero of six 'Marianna 2624' were infected. Our results demonstrate the sensitivity of molecular hybridization for TomRSV detection in Prunus and substantiate the TomRSV resistance of 'Marianna 2624'.
\end{abstract}

Tomato ringspot virus (TomRSV), a member of the nepovirus group, causes disease in economically important woody fruit, ornamental, and herbaceous hosts (Stace-Smith, 1984). It is a serious problem for peach orchards in the northeastern United States, where it has caused Prunus stem pitting disease (Smith et al., 1973). In prune and plum, TomRSV also has caused brownline disease (Hoy and Mircetich, 1984). Trees infected with the virus exhibit poor growth, chlorotic and sparse foliage, thick spongy bark, pitting at the trunk base, growth decline, and eventually death. The virus is transmitted by the dagger nematode, who acquires the virus while feeding on the roots of infected orchard trees or broadleaf weeds that serve as TomRSV reservoirs. Because there are no remedial measures to cure infected trees, control recommendations center on disease prevention. Preventive measures include using virus-free plants, controlling broadleaf weeds, and chemically controlling nematode populations.

Received for publication 5 Jan. 1994. Accepted for publication 30 Apr. 1994. The cost of publishing this paper was defrayed in part by the payment of page charges. Under postal regulations, this paper therefore must be hereby marked advertisement solely to indicate this fact.
Another approach for TomRSV control is using resistant varieties; however, all currently cultivated, commercial peach rootstocks are susceptible. Hoy and Mircetich (1984) reported the plum rootstock Marianna 2624 to be TomRSV resistant in California studies on prune brownline disease. Marianna 2624 is not suitable for peach rootstock use, but it demonstrates that TomRSV resistance exists in Prunus. Screening peach rootstocks for TomRSV resistance in the field is complicated by several factors: 1) length of time required (often several years) to complete orchard tests, 2) inconsistent results because of difficulty finding or establishing sites that have a uniform TomRSV and nematode distribution, and 3) difficulty in TomRSV detection by enzyme-linked immunosorbent assay (ELISA) because of unevenly distributed virus in infected trees (Bitterlin et al., 1988) and antisera reacting anomalously with host antigens (Mink et al., 1985).

Recently, Powell et al. (1991) compared TomRSV detection by ELISA with dot blot hybridization detection using a complementary RNA (cRNA) radiolabeled probe. They reported that the nucleic acid probe was more efficient in detecting TomRSV from orchardgrown nectarine trees with Prunus stem pitting disease. This paper describes the develop- ment of a rapid assay for screening Prunus germplasm for TomRSV resistance. The test is based on the natural infection of greenhouse-grown, candidate plants with TomRSV using the nematode vector. This is followed by virus detection through molecular hybridization using a cRNA probe. The combination of greenhouse-grown plants and the sensitive dot-blot molecular hybridization assay allows screening to be completed within 10 to 20 weeks. Halbrendt et al. (1991) have presented preliminary results.

\section{Materials and Methods}

Nematode-infested soil was collected from a Prunus stem pitting-diseased nectarine orchard at Pennsylvania State Univ. Fruit Research Laboratory, Biglerville. The soil was planted with a variety of naturally TomRSVinfected broadleaf weeds, including dandelion (Taraxacum officinale Weber ex Wiggers) and chickweed [Stellaria media (L.) Villars], and was maintained in a greenhouse. The nematode population was assayed periodically by planting virus-free 'National Pickling' cucumbers (Cucumis sativus L.) in the infested soil. All cucumber bait plants subsequently tested positive for TomRSV. Nematode-infested soil was diluted with sterile soil to a concentration of 38 Xiphinema americanum per $100 \mathrm{cc}$ of soil and planted with test trees.

The U.S. Dept. of Agriculture's Appalachian Fruit Research Station, Kearneysville, W.Va., provided 5- to 7-year-old, TomRSVfree plum ('Stanley' and 'Marianna 2624') and peach ('Redhaven' and 'Halford') plants. Sprouted nodal cuttings (Robitaille and $\mathrm{Yu}$, 1980) were dipped in a 500-ppm solution of indolebutyric acid and rooted in perlite under intermittent misting for $4 \mathrm{sec}$ at 15 -min intervals. Rooted cuttings were transplanted to nematode-infested soil after 8 to 10 weeks. Twenty rooted 'Marianna 2624' cuttings were transplanted to fumigated soil to serve as nontreated controls. Three naturally infected Prunus stem pitting-diseased, orchard peach trees and TomRSV-inoculated plants of the herbaceous indicator Chenopodium quinoa were used as positive controls.

Test trees were sampled 10 and 22 weeks after transplanting to infested soil. After the second sampling, trees were placed in cold storage for 10 weeks at 0 to $2 \mathrm{C}$. The last samples were taken 1 week after the artificially induced dormancy ended, $\approx 34$ weeks after transplanting. About $1.0 \mathrm{~g}$ each of washed root and leaf tissue was sampled per plant. The tissues were powdered in liquid $\mathrm{N}_{2}$, using a chilled mortar and pestle, then mixed immediately with $10.0 \mathrm{ml}$ of PBS-Tween-PVP (phosphate-buffered saline, $15 \mathrm{~mm} \mathrm{Na} \mathrm{HPO}_{4}, 150$ mu NaCl, $0.05 \%$ Tween- $20,2.0 \%$ polyvinylpyrrolidone, $\mathrm{Mr}=40,000, \mathrm{pH} 7.4)$. Aliquots, $1.0 \mathrm{ml}$ each, were withdrawn and used for ELISA and bioassay by mechanical inoculation to $C$. quinoa. The remaining homogenate was clarified by extracting with 1.0 volume of 25 phenol : 24 chloroform : 1 octanol. After precipitation with 0.1 volume sodium acetate 
Table 1. Detection of tomato ringspot virus in nematode-inoculated peach and plum seedling nucleic acid extracts. ${ }^{2}$

\begin{tabular}{|c|c|c|c|c|c|c|c|c|c|c|c|c|c|}
\hline \multirow{4}{*}{$\begin{array}{l}\text { Assay } \\
\text { method }\end{array}$} & \multirow{4}{*}{$\begin{array}{l}\text { Sampling time } \\
\text { (weeks) }\end{array}$} & \multicolumn{12}{|c|}{ Tomato ringspot virus detection ${ }^{y}$} \\
\hline & & \multicolumn{8}{|c|}{ Variety } & \multirow{2}{*}{\multicolumn{2}{|c|}{$\begin{array}{c}\text { Positive }^{\mathrm{x}} \\
\text { control }\end{array}$}} & \multirow{2}{*}{\multicolumn{2}{|c|}{$\begin{array}{l}\text { Negative }^{w} \\
\text { control }\end{array}$}} \\
\hline & & \multicolumn{2}{|c|}{ Stanley } & \multicolumn{2}{|c|}{ Halford } & \multicolumn{2}{|c|}{ Redhaven } & \multicolumn{2}{|c|}{ Marianna } & & & & \\
\hline & & Root & Leaf & Root & $\overline{\text { Leaf }}$ & Root & Leaf & $\overline{\text { Root }}$ & $\overline{\text { Leaf }}$ & Root & $\overline{\text { Leaf }}$ & Root & $\overline{\text { Leaf }}$ \\
\hline \multirow[t]{3}{*}{ Bioassay } & 10 & $0 / 2$ & $1 / 2$ & $0 / 3$ & $0 / 3$ & $1 / 5$ & $0 / 5$ & $0 / 6$ & $0 / 6$ & $3 / 3$ & $0 / 3$ & $0 / 3$ & $0 / 3$ \\
\hline & 22 & $0 / 2$ & $0 / 2$ & $0 / 3$ & $0 / 3$ & $2 / 5$ & $1 / 5$ & $0 / 6$ & $0 / 6$ & $1 / 2$ & $0 / 2$ & $0 / 3$ & $0 / 3$ \\
\hline & $34^{\mathrm{v}}$ & $0 / 2$ & $0 / 2$ & $0 / 3$ & $0 / 3$ & $0 / 5$ & $0 / 5$ & $0 / 6$ & $0 / 6$ & $2 / 2$ & $0 / 2$ & $0 / 3$ & $0 / 3$ \\
\hline \multirow[t]{3}{*}{ Dot blot } & 10 & $2 / 2$ & $1 / 2$ & $3 / 3$ & $1 / 3$ & $4 / 5$ & $0 / 5$ & $0 / 6$ & $0 / 6$ & $3 / 3$ & $0 / 3$ & $0 / 3$ & $0 / 3$ \\
\hline & 22 & $2 / 2$ & $0 / 2$ & $3 / 3$ & $2 / 3$ & $5 / 5$ & $3 / 5$ & $0 / 6$ & $0 / 6$ & $1 / 2$ & $0 / 2$ & $0 / 3$ & $0 / 3$ \\
\hline & 34 & $0 / 2$ & $0 / 2$ & $1 / 3$ & $0 / 3$ & $3 / 5$ & $0 / 5$ & $0 / 6$ & $0 / 6$ & $2 / 2$ & $0 / 2$ & $0 / 2$ & $0 / 2$ \\
\hline
\end{tabular}

${ }^{2}$ Thirty-eight Xiphinema americanum per 100 cc soil.

y Number of tomato-ringspot-virus-positive plants per test plant total.

${ }^{x}$ Field-grown, Prunus stem pitting-diseased trees.

w'Marianne 2624' cuttings grown in nematode-free, sterilized soil.

${ }^{\mathrm{v}}$ After 22 weeks, plants were stored for 10 weeks at 0 to $2 \mathrm{C}$ and sampled 1 week after being returned to greenhouse.

(pH 5.2) and 2.5 volume ethanol, total nucleic acids were collected by centrifuging and resuspended in $0.5 \mathrm{ml}$ autoclaved distilled water. For dot blots, a 0.1-ml aliquot of each total nucleic acid sample was withdrawn and denatured by heating for $30 \mathrm{~min}$ at $60 \mathrm{C}$ with an equal volume of $8 \times \mathrm{SSC}-15 \%$ formaldehyde (SSC is $150 \mu \mathrm{M}$ sodium chloride, $15 \mu \mathrm{M}$ sodium citrate). Samples were immediately chilled on ice, then stored at $-20 \mathrm{C}$ until 5.0- $\mu \mathrm{l}$ aliquots were spotted onto $20 \times \mathrm{SSC}$-saturated nitrocellulose membranes. After air-drying, membranes were baked in vacuo for $2 \mathrm{~h}$ at $80 \mathrm{C}$ and stored desiccated at room temperature.

The plasmid transcription vector pSP64 containing an insert complementary to a 1.7$\mathrm{kb}$ segment of TomRSV RNA 2 (Hadidi and Powell, 1991) was linearized using Eco RI. Complementary RNA Riboprobes were synthesized using the linearized plasmid, ${ }^{32} \mathrm{P}$ UTP $[800 \mathrm{Ci} / \mathrm{mm}(1 \mathrm{Ci}=37 \mathrm{GBq})]$ and SP6 RNA polymerase (Promega Biotech, Madison, Wis.), according to the manufacturer's directions. Prehybridization was performed at $55 \mathrm{C}$ for $1 \mathrm{~h}$ in $40 \%$ formamide, $10 \%$ dextran sulfate, $20 \mathrm{~mm}$ sodium cacodylate buffer $(\mathrm{pH}$ 7.0), $180 \mathrm{~mm}$ sodium chloride, $1.0 \mathrm{~mm}$ ethylenediaminetetraacetic acid (EDTA), $0.1 \%$ sodium dodecyl sulfate (SDS), and $400 \mu \mathrm{g}$ yeast tRNA/ml. The Riboprobe was added at $1 \times 10^{6} \mathrm{cpm} / \mathrm{ml}$ and incubated 16 to $20 \mathrm{~h}$ at $55 \mathrm{C}$. Membranes were washed three times in $2 \times \mathrm{SSC}$ for $15 \mathrm{~min}$ at room temperature, once in $2 \times \mathrm{SSC}$ with RNase A at $1.0 \mu \mathrm{g} \cdot \mathrm{ml}^{-1}$ for 15 min at room temperature, and once with $0.1 \times$ SSC $-0.1 \%$ SDS for $30 \mathrm{~min}$ at $65 \mathrm{C}$. Then they were air-dried. Autoradiographs were made by exposing film (X-AR; IBI/Kodak, New Haven, Conn.) to membranes for 16 to $20 \mathrm{~h}$ at $-70 \mathrm{C}$, with an intensifying screen.

\section{Results and Discussion}

When the four Prunus varieties, two peaches and two plums, were inoculated with TomRSV using Xiphinema nematodes, only the plum rootstock Marianna 2624 did not become infected (Table 1, Fig. 1). None of the six 'Marianna 2624' trees indexed positive at any sampling date, but dot blot hybridization of root extracts indicated that two of two 'Stanley', three of three 'Halford', and five of five 'Redhaven' trees indexed positive for at least one sampling date. These results support

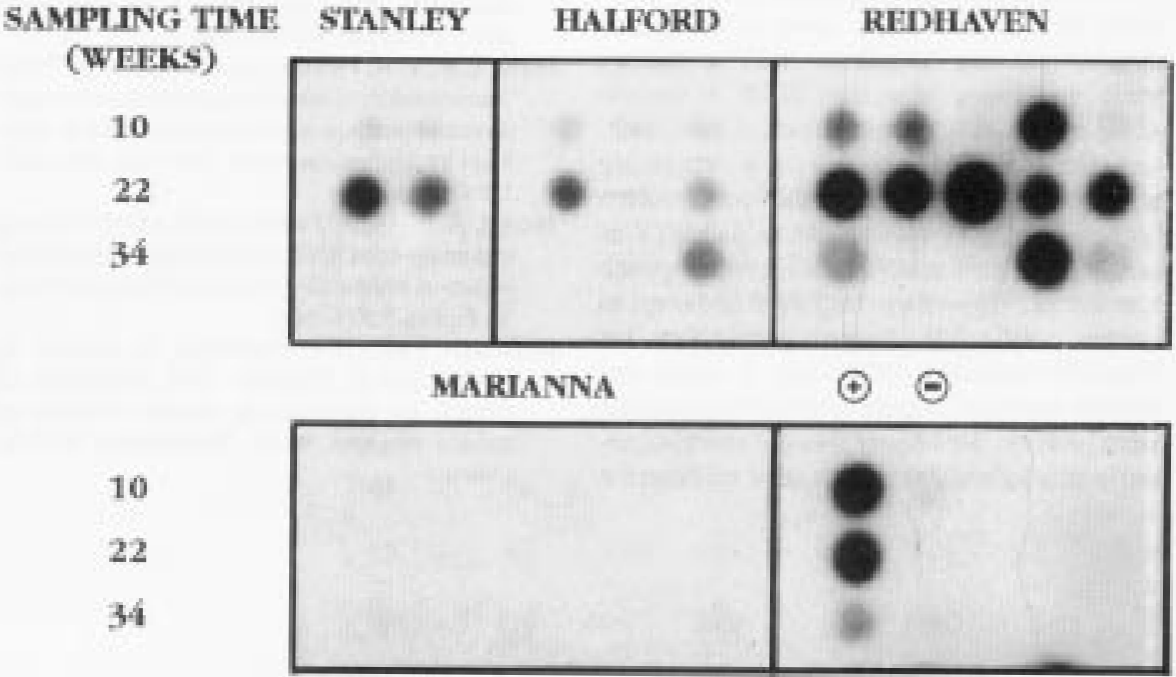

Fig. 1. Detection of tomato ringspot virus by dot blot hybridization of root extracts from peach and plum rooted cuttings inoculated with viruliferous nematodes. Columns correspond to individual plants tested. Rows are grouped according to sampling date. Plants were placed in cold storage from weeks 23 to 33 to induce dormancy. Positive controls (+) consisted of naturally Prunus stem pitting disease-infected 'Redhaven' trees. Negative controls (-) were 'Marianna 2624' cuttings grown in nematode-free, sterilized soil.

those of Hoy and Mircetich (1984), who reported that 'Marianna 2624' was resistant to TomRSV infection by grafting and by nematode inoculation. Their study, conducted in the orchard, required three growing seasons to complete. Our study demonstrated that by using greenhouse-grown rooted cuttings and dot blot hybridization, similar results can be obtained within 10 to 22 weeks and can be conducted year-round. Forer et al. (1984) found that ELISA detection of TomRSV in nematode-inoculated peach seedlings improved after an artificially induced dormancy. This was not the case in our study, and the detection rate and possibly virus titer dropped immediately after dormancy (Fig. 1).

We chose to use nematode rather than mechanical or graft inoculation of candidate trees for several reasons. We felt that nematode inoculation was a convenient and reliable method for inoculating Prunus seedlings; it is sometimes difficult to infect woody hosts with TomRSV by mechanical inoculation. Bitterlin et al. (1987) reported $0 \%$ to $100 \%$ infection rates using several mechanical and graft inoculation methods. In their study, a knifeslash method proved most reliable, producing infections in $50 \%$ to $100 \%$ of inoculated Prunus seedlings. These infection rates are similar to those we obtained using nematodes, but the knife-slash method requires 3 - to 10 month-old seedlings as test plants and 6 to 11 more months to reach detectable TomRSV levels. It also has been reported that graft inoculation in grapevines (Vitis labrusca L.) may overcome normal resistance mechanisms (Stobbs et al., 1988). Bouquet (1981) reported that muscadine grape (Vitis rotundifolia Michx.) did not become infected by grape fanleaf virus when exposed to viruliferous nematodes (Xiphinema index Thorne and Allen) but was susceptible when inoculated by graft. Nematode TomRSV transmission represents the natural field condition. Valuable resistance to TomRSV or transmission by its nematode vector might be overlooked using graft or mechanical inoculation.

Our results support the conclusions of previous studies in which TomRSV detection was more reliable in root vs. leaf tissue (Forer et al., 1984; Lister et al., 1980). Although TomRSV was occasionally detected in leaf tissue, reactions from root tissue proved stronger and more consistent (Table 1, Fig. 2). 


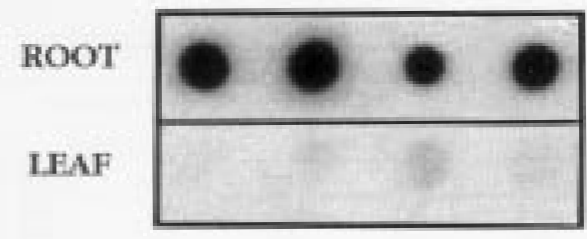

Fig. 2. Dot blot hybridization assay of paired root and leaf total nucleic acid extracts from individual, tomato-ringspot-virus-infected, 'Redhaven' peach cuttings.

Presumably, one might expect the highest virus titers in the roots of such young plants because the plants were inoculated through root feeding by viruliferous nematodes.

Our data support the conclusion that resistance to TomRSV does exist in the genus Prunus and that 'Marianna 2624' possesses such resistance. 'Marianna 2624' is unsuitable, however, for use as a peach rootstock. Lovell and Halford, the two most commonly used peach rootstocks in the northeastern United States, are susceptible to TomRSV as are all the commercially cultivated peach rootstocks. These facts highlight the need to screen compatible Prunus germplasm for TomRSV-resistant rootstocks. A rapid and reliable means of screening the germplasm has been lacking. We believe that the greenhousemolecular hybridization assay that we describe provides a rapid and reliable method for screening Prunus germplasm for TomRSV resistance in 10 to 22 weeks and in a way that more closely approximates potential field resistance than mechanical inoculation methods.

\section{Literature Cited}

Bitterlin, M.W., D. Gonsalves, and J.G. Barrat. 1988. Distribution of tomato ringspot virus in peach trees: Implication for viral detection. Plant Dis. 72:59-63.

Bitterlin, M.W., D. Gonsalves, and R. Scorza. 1987. Improved mechanical transmission of tomato ringspot virus to Prunus seedlings. Phytopathology 77:560-563.

Bouquet, A. 1981. Resistance to fanleaf virus in muscadine grape inoculated with Xiphinema index. Plant Dis. 65:791-793.

Forer, L.B., C.A. Powell, and R.F. Stouffer. 1984. Transmission of tomato ringspot virus to apple rootstock cuttings and to cherry and peach seedlings by Xiphinema rivesi. Plant Dis. 68:10521054.

Hadidi, A. and C.A. Powell. 1991. cDNA cloning and analysis of RNA 2 of a Prunus stem pitting isolate of tomato ringspot virus. Mol. and Cellular Probes 5:337-344.

Halbrendt, J.M., E.V. Podleckis, R. Scorza, A. Hadidi, and R. Welliver. 1991. Evaluation of Prunus for resistance to natural infection of tomato ringspot virus. HortScience 26:748. (Abstr.)
Hoy, J.W. and S.M. Mircetich. 1984. Prune brownline disease: Susceptibility of prune rootstocks and tomato ringspot virus detection. Phytopathology 74:272-276.

Lister, R.M., W.R. Allen, D. Gonsalves, A.R. Gotlieb, C.A. Powell, and R.F. Stouffer. 1980. Detection of tomato ringspot virus in apple and peach by ELISA. Acta Phytopathol. Acad. Sci. Hungaricae 15:47-55.

Mink, G.I., W.E. Howell, and P.R. Fridlund. 1985. Apple leaf tip antigens that cause spurious reactions with tomato ringspot virus antisera in enzyme-linked immunosorbent assay. Phytopathology 75:325-329.

Powell, C.A., A. Hadidi, and J.M. Halbrendt. 1991. Detection of tomato ringspot virus in nectarine trees using ELISA and transcribed RNA probes. HortScience 26:1290-1292.

Robitaille, H.A. and K.S. Yu. 1980. Rapid multiplication of peach clones from sprouted nodal cuttings. HortScience 15:579-580.

Smith, S.H., R.F. Stouffer, and D.M. Soulen. 1973. Induction of stem pitting in peaches by mechanical inoculation with tomato ringspot virus. Phytopathology 63:1404-1406.

Stace-Smith, R. 1984. Tomato ringspot virus. no. 290. Descriptions of plant viruses. Cmwlth. Mycol. Inst. and Assn. Applied Biologists, Surrey, England.

Stobbs, L.W., J.W. Potter, R. Killins, and J.G. van Schagen. 1988. Influence of grapevine understock in infection of DeChaunac scion by tomato ringspot virus. Can. J. Plant Pathol. $10: 228-231$. 